\title{
14. 'Places left behind': national urban policy in the UK - from boom to slump and recovery?
}

\author{
Andrew Tallon
}

\section{INTRODUCTION}

Urban regeneration is a diverse, multi-disciplinary and significant component of urban studies globally. Since the mid-twentieth century in the UK, national urban regeneration has endeavoured to deal with economic, social and environmental problems that cities have experienced as a result of factors such as the decline of manufacturing industry and the growing intensity of competition between cities at the global level. Cities across the developed and developing world have experienced striking and profound changes since the mid-twentieth century. Their economic bases, their social composition, their physical landscapes, their modes of governance, and their relationships with host nations and with other cities, have all been transformed. Through time, urban policy has consistently sought to level up 'places left behind' in terms of economic growth (Bolton et al. 2020).

The term 'left behind' has become common currency since the 2016 UK referendum vote to leave the European Union. 'Left behind' places are those that have been bypassed by the economic prosperity from which others have benefited. They are concentrated in post-industrial and coastal areas, and often housing estates on the peripheries of towns and cities. Residents in these areas have markedly worse socio-economic outcomes compared with those living in similarly deprived areas, and they have fewer job opportunities, lower levels of educational attainment and poorer health (Bolton et al. 2020).

Urban regeneration can be defined as a 'comprehensive and integrated vision and action which leads to the resolution of urban problems and which seeks to bring about a lasting improvement in the economic, physical, social and environmental conditions of an area that has been subject to change' (Roberts 2017, p. 18). 'The large-scale process of adapting the built environment, with varying degrees of direction from the state, is today generally 
referred to (...) as urban regeneration' (Jones and Evans 2013, p. 2), indicating the importance of national-level direction. Urban policy in the UK is generally accepted to include programmes and initiatives targeted at resolving social and economic, and intermittently environmental, problems in the most deprived areas, generally those former industrial heartlands. The sponsoring government departments have historically been those of the environment, communities and local government, and this remains the case. In the UK, related issues of energy, resources and climate change have an 'urban dimension' but have been dealt with by separate government departments and policy bundles. These are referred to as variously environment policy, energy policy, climate change policy and such, rather than 'urban' policy.

In this wider context, this chapter gives a historic and contemporary overview of national urban policy, and critiques national urban policy initiatives implemented by central governments during the postwar period in the UK. The chapter first aims to provide a wider context for national urban policy in the UK; second to briefly outline successive periods of urban policy in the UK from the immediate postwar period until the start of the 2020 s, across sequential episodes of boom followed by slump followed by apparent recovery; third to focus particularly on national urban policy in the last decade; and fourth to give a broad assessment of national urban policy in the UK from the 1960s to the 2020 s.

\section{THE CONTEXT FOR NATIONAL URBAN POLICY IN THE UK}

There is striking evidence to show that cities across the world have undergone these dramatic transformations since the mid-twentieth century, and particularly since the 1970s. These changes have been referred to as part of a shift from the 'modern' or industrial city to the 'postmodern' or post-industrial city (Tallon 2013). Major processes have been at work which have driven and shaped the changes which have benefited some places and groups in society but not others that remain left behind. Understanding these processes helps make sense of how and why cities are changing and the implications for urban policy. These processes encompass post-industrialisation, as reflected in the shift from production to consumption and knowledge services (Short and Kim 1999); globalisation and its multiple dimensions (Begg 1999; Short and Kim 1999); changing landscapes of inequality and exclusion (Levitas 2005); growing social and cultural diversity (Forrest and Kearns 2001; Kearns 2003); the emergence of new forms of urban governance (Harvey 1989; Hall and Hubbard 1996; Andrew and Goldsmith 1998); and the development of new types of urban space (Dear 1995; Soja 1995). All of these are inextricably linked with urban regeneration policy as a global urban process. Making sense 
of these changes is challenging but vital for those with an interest in urban places if they are to understand and intervene effectively in continuing and evolving processes of urban change through national urban policy.

Each of these six major processes of change at work since the mid-twentieth century is closely linked with urban regeneration and urban policy. They illustrate how and why urban landscapes have changed, who the beneficiaries are, and what the implications are for the future of urban space globally. It is clear that since the late 1970s, urban regeneration has been underpinned by a focus on economic and property development, with intermittent attention paid to social and cultural issues in the UK. Particularly since the early 1990s, urban regeneration has been based on a series of assumptions linked to the macro-economy, including continued economic growth in the context of globalisation, low unemployment, low inflation, low interest rates, rising property values and increasing owner-occupation of housing. Much successful urban regeneration had taken place during the period prior to the global economic crash, but this abruptly came to an end after 2007/2008. Economic recession, housing market decline and a contraction in manufacturing industry, and their impacts on the private sector and consumers, along with a significant reduction in public spending, have had severe impacts upon urban regeneration and urban policy through a whole decade of austerity. Lessons for urban regeneration and urban policy in the UK context can be drawn from past central government policies to inform a new urban policy in the 2020s to level up the 'places left behind'.

\section{PHASES OF NATIONAL URBAN POLICY IN THE UK}

There have been a number of distinct thematic shifts in urban policy in the UK since the Second World War, which are illustrated in general by Table 14.1. This shows the periodisation used to frame successive periods covered in this chapter, which illustrates continuities and changes in UK urban policy over more than 70 years. This section will chart urban policy chronologically over the decades through to the present day. It should be cautioned that these historical periods are not mutually exclusive. As Hall and Barrett (2012, p. 151) warn, 'While it is tempting to characterize urban policy in a series of distinct periods of development, this tends to underemphasize the degree of continuity between periods and overemphasise a clear sequential trajectory to policy development.' Despite this reservation, Hall and Barrett (2012, p. 151) go on to suggest that 'as a pedagogic device the periodization of urban policy does have some merit when viewed in broad terms'.

In terms of UK national urban policy, broad phases of policy responses can be distilled as shown by Tables 14.1 and 14.2, although it must be recognised 
that these are to an extent generalised and not mutually exclusive. A postwar period of physical redevelopment and area-based social welfare projects dominated in the UK and many other Western European and North American countries. Approaches focused upon improving living conditions in cities and providing services and infrastructure for increasing urban populations (Couch 1990; Atkinson and Moon 1994). Urban redevelopment following the end of the Second World War aimed to redevelop declining and war-damaged housing and commercial areas. The approach was physical and thus failed to tackle growing economic and social inequalities generated by structural economic and social change. Town and country planning and new standards for housing development were also introduced to tackle the problems of urban sprawl and poor construction. Urban redevelopment was largely funded and regulated by the public sector, and during this period local-central government relations were much more closely aligned to achieve urban redevelopment objectives (see Atkinson and Moon 1994). By the mid-1960s, continuing and entrenched problems of poverty and growing racial disquiet were recognised by national government. The response was the implementation of a distinct urban policy for the first time in the UK in 1968, and the first wave of area-based social and welfare policies targeted at the most deprived areas of cities (see Table 14.2). These initially took a social pathology approach to the problem, blaming the victims for their plight, and aimed at promoting self-help in communities and improving public services. However, the policies were hampered by a lack of knowledge of the causes of the urban problem, the shortcomings of the social pathology model, and a lack of coherence of these policies (Atkinson and Moon 1994). The events that took place during the early-to-mid 1970s were to have a profound impact on the ideological and political nature of urban policy. A severe structural crisis resulted in rising unemployment and significant economic decline. The lack of effectiveness and subsequent loss of faith in Keynesian demand management economics created a context from which the New Right emerged, characterised by a sustained attack on the postwar consensus, and emphasising a minimal state, individual liberty, choice, the free market and the entrepreneurial spirit.

Thus, by the early 1980s, neo-liberalism emerged as the key model for managing the UK economy. Entrepreneurial and property-led regeneration dominated urban policy responses in the US and UK in particular, as a perceived solution to urban economic and environmental problems (Turok 1992; Imrie and Thomas 1993). Atkinson and Moon (1994) argued that the verdict on the general approaches to urban regeneration during the 1980s was predominantly negative. On the whole, policies failed to create sufficient service sector jobs to replace those lost in manufacturing. Additionally, the types of jobs and the nature of the built environment required by service industries were somewhat different from those of manufacturing industry. Social and spatial 
inequalities continued to widen, especially in cities. Finally, and paradoxically, general approaches such as property-led regeneration were dependent on state resources. In response to the severe criticisms, the Audit Commission (1989) concluded that urban policy in the 1990s should attempt to overcome these problems. The report argued that policy should be more straightforward and less complex, and that local authorities should take a more active role in policy formation and instigation (Jacobs 1992). Urban policy in the 1990s should therefore place the problem of social inequality and related unemployment, poverty and social segregation at its centre, and not just focus on economic development (Oatley 1995). It should also integrate public and private efforts at urban regeneration and include mechanisms that ensure that local residents derive some benefits from developments. It was recognised that market mechanisms alone were unable to ensure an effective, efficient and equitable allocation of investment and employment opportunities.

Economic competition in urban policy emerged as a model for distributing urban funds in the UK and elsewhere during the 1990s (see Oatley 1998), a period which also saw a re-integration of social and environmental aims with economic imperatives. From the late 1990s until the early 2010s, urban regeneration sought to combine economic development and social justice in urban policy, through urban renaissance and neighbourhood renewal policies such as Grands Projets de Ville (GPV) in France, Kvarterløft ('neighbourhood uplift') in Denmark, New Deal for Communities (NDC) in England and Soziale Stadt ('Social City') in Germany. Urban policy remained a confusing landscape in the mid-1990s. Attempts had been made to mitigate this criticism as the Single Regeneration Budget merged 20 existing programmes and rendered the 1980s policy programmes irrelevant. This seemingly brought to fruition the promise of coordination and more strategic thinking, as did bringing local authorities back into the urban policy and regeneration process. However, commentators remained unconvinced and Robson et al. (1994) feared that the swing back towards local authorities went too far and that there was little evidence of a strategic vision for urban policy. Herbert (2000) argued that schemes such as City Challenge did not amount to a clear inner-city strategy.

In addition to official government evaluations and summaries (see for example CLG 2008; 2009), there are a limited number of general evaluations of urban renaissance and neighbourhood renewal policy between 1997 and 2010 (Shaw and Robinson 2010; Tallon 2013). More common are assessments of particular policies, for example of NDCs (Lawless 2010; 2011; Lawless and Beatty 2013). Shaw and Robinson (2010, p. 123) argued that 'while New Labour's approach since 1997 has been distinctive and, in some respects, innovative, especially in relation to community engagement, it has continued to adopt a flawed conception of the urban problem which has led to a limited policy response'. 
Neighbourhood renewal programmes under New Labour aimed to target resources at the most disadvantaged neighbourhoods to tackle multiple deprivation and improve public services (Smith et al. 2007). The flagship New Deal for Communities programme targeted 39 of the most deprived neighbourhoods in England, which each received around $£ 50$ million over a ten-year period. Although resulting in some modest improvements in those areas targeted by neighbourhood renewal area-based initiatives (ABIs), the problems of ABIs as a concept continued to attract criticism (Shaw and Robinson 2010; Matthews 2012). They were allocated relatively limited resources through which to tackle pre-determined problems for pre-determined periods of time (Lawless 2010). Assessing the impacts of ABIs such as the flagship NDC programme is tricky because of problems establishing the counterfactual (Lawless 2010; 2011). Further, it would be unrealistic to claim that ABIs could regenerate entire towns or cities, because of their tightly defined areas (Lawless 2010). However, NDCs were the most intensively funded and one of the most significant ABIs ever devised and tackled previous shortcomings of short termism, lack of focus and inadequate community engagement (Lawless 2010). Five key highlights of NDCs as the flagship ABI were identified by Lawless (2010). First, ABIs tend to improve places rather than the fortunes of individuals within them; employment and economic development objectives are better suited to city-regional and national interventions. Second, involving and engaging community is fraught with problems; there is no evidence of increased social capital and often there is heightened conflict over decisions. Third, size matters as bigger NDC partnership areas were associated with more positive gains than smaller ones. Fourth, NDCs worked with a wide range of agencies to achieve positive change in relation to all six outcomes, but in dealing with mainstream organisations, regeneration partnerships need to be outcome focused, realistic in terms of what can be achieved and selective with whom they engage. Fifth, there is a tension in achieving an appropriate balance of power between central government, on the one hand, with local government and local residents, on the other.

\section{4. $\quad$ NATIONAL URBAN POLICY IN THE UK IN THE $2010 \mathrm{~S}$}

Urban regeneration policy appeared to have returned to the 1980 s during the 2010s with the driving force being economic growth in response to the credit crunch and resulting global financial crisis from 2007/2008. This led to an era of austerity politics with central government funding to local authorities being significantly reduced by around 40 per cent and area-based regeneration schemes finishing (Hall 2015; Lowndes and Gardner 2016). At the same time, the philosophy of localism and devolution of powers has been promoted to 


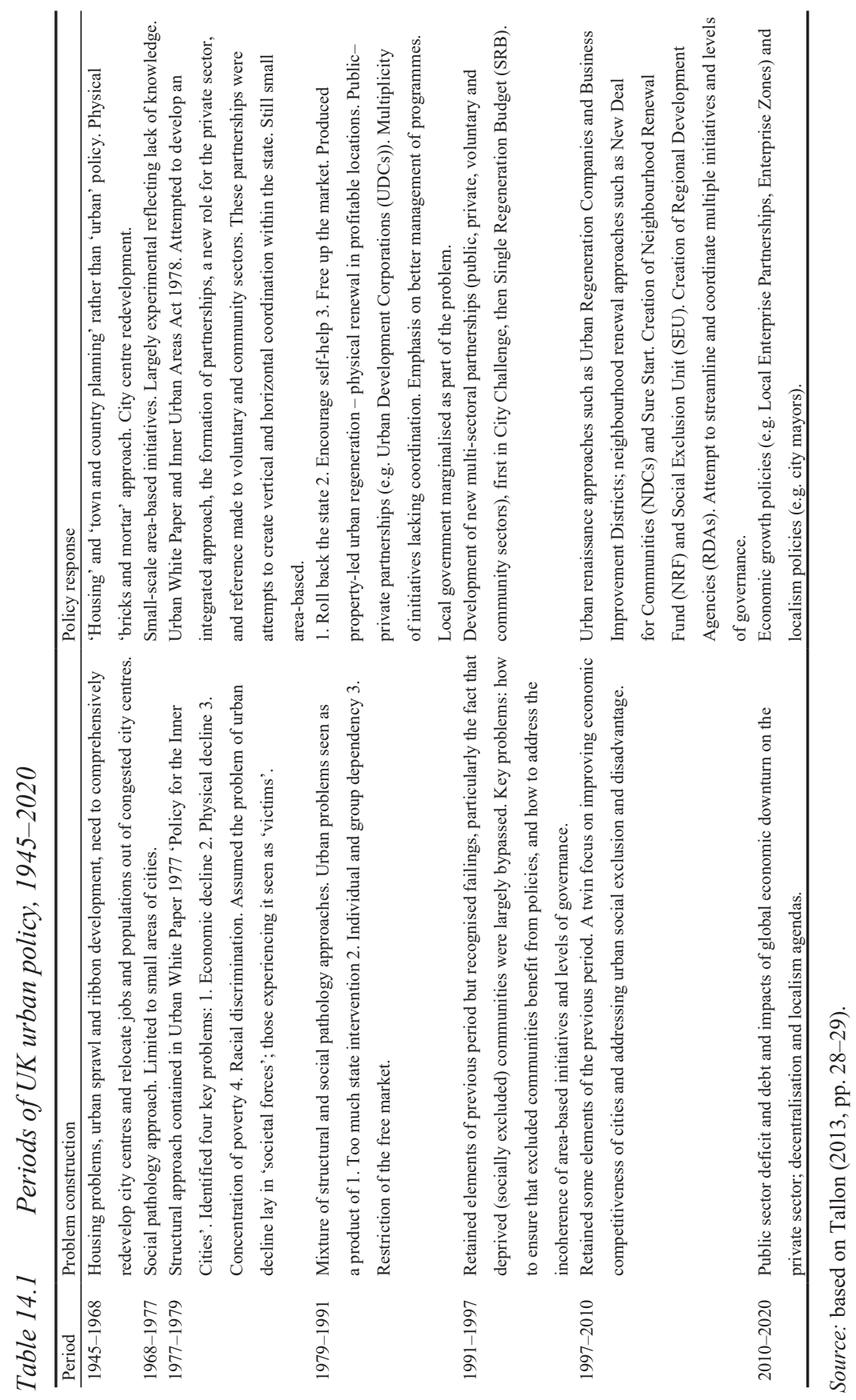




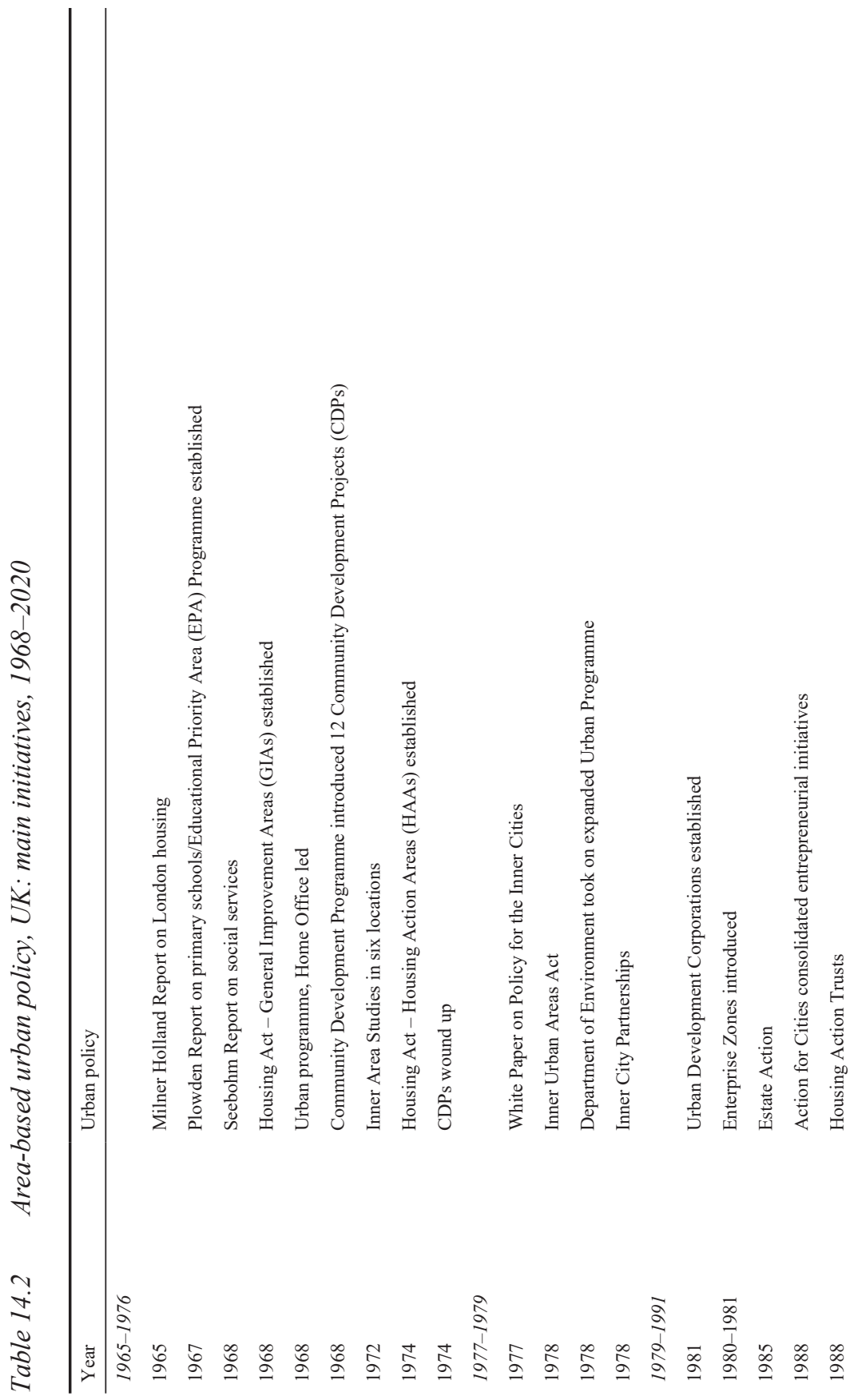




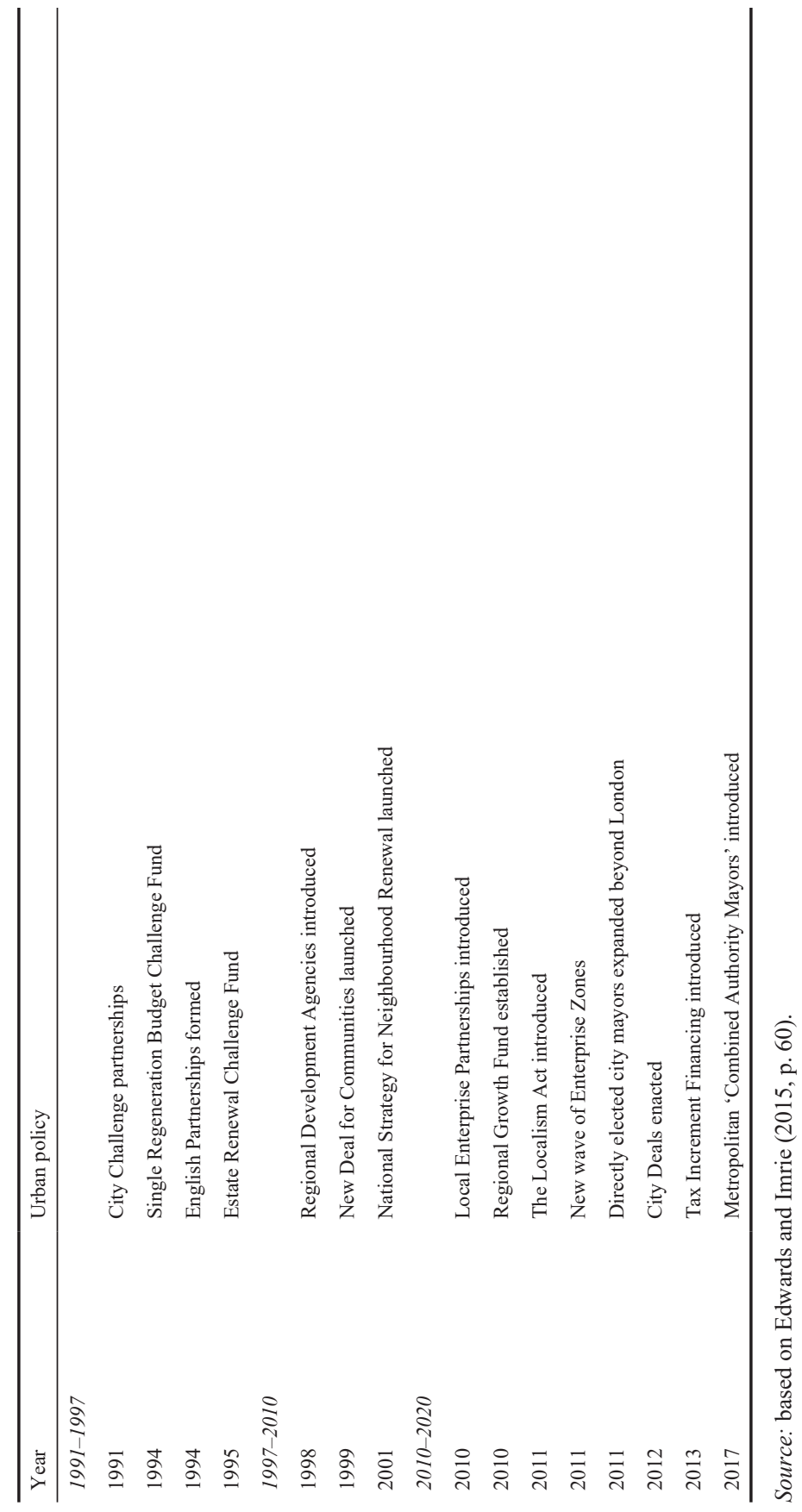


an extent (Hambleton 2015; 2017) and the regional level of governance has been abolished (Pike et al. 2018). Limited additional resources have been provided by central government for these new institutional arrangements, with the emphasis being on encouraging market forces and attracting development to particular areas of cities, along the lines of the approaches of the Thatcher governments of the 1980s.

Urban regeneration policy since the 1980 s has principally been about correcting market failure, with regeneration being 'the broad process of reversing physical, economic and social decline in an area where market forces will not do this without intervention' (CLG 2011). However, the urban problem as demonstrated by the 2019 Indices of Deprivation remains as entrenched as ever (MHCLG 2019). The enterprise culture espoused by Michael Heseltine in the 1980s was exemplified by policies such as Enterprise Zones, with 38 designated between 1981 and 1996 (Jones 2006), Urban Development Corporations, of which 13 were created (Imrie and Thomas 1999), and Estate Action (Pinto 1993). This was followed by the challenge funding model of the 1990s, embracing principles of competition, partnership, targeting of resources and comprehensive regeneration whilst being time limited and output monitored (Oatley 1998). The initiatives of City Challenge (Davoudi and Healey 1995) and Single Regeneration Budget (Rhodes et al. 2005) were flagship policies of the period. The latter programme comprised six competitive rounds which resulted in 1027 regeneration projects equating to over $£ 5.7$ billion in financial support and $£ 26$ billion of total expenditure across England, £9 billion of which came from the private sector. During the 2000s, the 'third way' principles of supply-side intervention, local intervention, partnership, participation and public investment dominated urban policy (Tiesdell and Allmendinger 2001). Key initiatives were neighbourhood renewal (Smith et al. 2007), urban renaissance (Colomb 2007) and sustainable communities (Raco 2007). Then in the most recent phase of urban policy during the $2010 \mathrm{~s}$, localism as a principle was articulated in the context of 'broken Britain', a 'post bureaucratic age' and devolution (Clarke and Cochrane 2013; Hall 2015). Key initiatives included Local Enterprise Partnerships, Enterprise Zones, Tax Increment Financing, the Regional Growth Fund and City Deals (Pugalis and McGuinness 2013). However, these policies were expected to be successful in an age of austerity urbanism which has witnessed a differential impact of local government cuts affecting the most deprived areas the greatest (Hastings et al. 2015; 2017) and of wider welfare reform (Beatty and Fothergill 2013; 2016).

The evaluation of urban policy, as will follow in the next section, over the decades since the 1960s has been a challenge due to methodological problems 
associated with the '5Cs': counterfactual, confound, contextual, combinatorial and choice (Robson et al. 1994). Action for Cities found that

public resources appear to have made an impact on turning around aspects both of the economic and residential distress in urban areas. But in the most deprived areas and especially in the conurbation cores and in areas of high unemployment - policy has not been able to make significant inroads into the socio-economic problems. (Robson et al. 1994, p. 49)

Further, evaluating New Labour's urban policy,

by 2007, evidence was indicating that NRF and mainstream government spending was generating large and noticeable improvements in neighbourhood environments and services; for example, new child care centres, health centres, community buildings, better neighbourhood management and policing and reduced crime, a higher standard of housing, new school buildings and extended services in schools, gaps in neighbourhood satisfaction were closing slightly, and residents reported that their neighbourhoods were getting better. (Lupton et al. 2013, p. 33)

However, evaluation of regeneration under the Coalition government found that

there is no evidence at present of the economic re-balancing that will be needed to underpin regeneration (...) there is no evidence yet of a spiral of decline amongst the poorest neighbourhoods but equally no evidence of further progress from the situation the Coalition inherited. Gaps remain very wide on key indicators. (Lupton and Fitzgerald 2015, p. 33)

In terms of contemporary debates, 'well funded Area Based Initiatives may have an important role to play in public good provision (e.g. better parks, lower crime) but they have not, on average, improved individual economic outcomes in targeted areas (...) overall, policy should focus on encouraging labour market activity and removing barriers to mobility' (Lawless et al. 2011, pp. 34-35).

Because of the similarity of the economic growth policies to those of the 1980s, several criticisms remain relevant. Potter and Moore (2000) found that Enterprise Zones might not be very good at attracting inward investment, might create low-skill jobs, and local businesses might simply relocate to zones. On the 45 new Enterprise Zones, Larkin and Wilcox (2011) took a pessimistic view, with concerns expressed over the regeneration of deprived areas no longer being a priority; limited new jobs being created by the original zones and at great expense; and displacement and deadweight effects being experienced. Therefore policies must minimise displacement and increase employment, reduce capital-based initiatives and relax planning regulations 
but recognise that they are not always a barrier to growth (Larkin and Wilcox 2011). Furthermore, any incentives should be matched to goals. Sissons and Brown (2011) identified three weaknesses of Enterprise Zones: job displacement, little being done to promote lasting economic prosperity, and high cost per job created. However, advantages of Enterprise Zones include that businesses can be attracted to depressed areas quickly, economic momentum can be generated, they can be a vehicle for improving competitiveness, and local market failures can be overcome. Sissons and Brown (2011) made three policy recommendations for such an economic growth initiative: they must be the right size to minimise displacement; they must address long-term competitiveness with investment targeted at skills, infrastructure and regeneration; and they must be free from conflict with national and local government.

Urban regeneration policy as commonly understood had largely disappeared from the discourse of public policy during the 2010s, and it can be argued that it did not exist at all as such, with a move away from area-based strategy (Crowley et al. 2012; Lupton and Fitzgerald 2015) and neo-liberal commentators who reject these arguments in favour of facilitating enhanced geographical mobility (Leunig and Swaffield 2008; Lawless et al. 2011) and a more recent move to focus on industrial strategy, productivity, competitiveness and investment in infrastructure (HM Government 2017). Going into the 2020s it appears that the UK remains in an era of 'post-urban policy' or 'after regeneration' (Hall 2015; O’Brien and Matthews 2016).

\section{EVALUATING NATIONAL URBAN POLICY IN THE UK IN THE 2020S}

As is evident from the successive periods of urban policy since the 1940s, each had its distinctive philosophies, approaches, achievements and weaknesses which governments of subsequent policy periods sought to address. Key lessons can be synthesised from the evidence of past experience to inform future approaches in the 2020s. Some of the weaknesses of urban policy were operational in nature related to particular policies or programmes, and other criticisms were wider and strategic in nature. Several categories of failure can be derived from an evaluation of the periods of national urban regeneration policy since the mid-1940s (Stewart 1987; Wilks-Heeg 1996; Shaw and Robinson 1998; Gripaios 2002; Tallon 2013; Edwards and Imrie 2015; Hall 2015).

First, it is evident that over time, in many national contexts, there has been a lack of clarity and purpose of urban policy. For example, the European Union has no formal urban policy as such; rather, it has policies that recognise the role of and impact upon urban areas such as regional policy and environmental policy. The objectives of urban policy initiatives driven by central government 
have often been too broad and ill-defined, and area-based initiatives are unable to realistically tackle the multiple problems faced by society. Imprecision of purpose has caused unrealistically high expectations, especially amongst local communities. Multiple objectives have meant that it has been difficult to set priorities and focus on feasible targets. Related to this problem with its remit, urban regeneration policy has seen insufficient commitment and resources from central governments over timescales which are too short-term for realistic change to be achieved in the UK. Some policies can be seen as token and a diversion from mainstream policies such as health and education. 'Quick fix' rather than long-term sustainable commitment has been an accusation levelled at central government urban policy in many European countries.

Second, excessive central government control of urban policy has often acted as a hindrance to urban regeneration and renewal at the local level. Governments have often been accused of being dictatorial about urban regeneration as it has been conducted in top-down fashion, reducing the scope for local solutions to local problems. Little analysis of local geographical context and the dominance of 'one size fits all' policies have resulted in little potential for flexibility, creativity or innovation in local urban regeneration and renewal. Central governments set a plethora of targets, give little room for local discretion, and cause friction amongst local partnerships, especially when government priorities have differed significantly from those at the local level (Johnstone and Whitehead 2004). Often partnerships have been forced together and have failed to cohere, and they have not been given enough time to develop and flourish under many policy initiatives (Atkinson 2003). Local authorities have few powers or resources to tackle urban policy issues in the context of a highly centralised country (Hambleton 2017). The short-lived Regional Development Agencies, established in 1998 and abolished by the Coalition government in 2010 as part of the austerity programme, were effective mechanisms (Pike et al. 2018). From 2010, much reduced central government finance was allocated to local authorities (Latham 2017). Hambleton (2019) argued that in essence the UK central state has chosen to decimate central government financial support to local government. Factoring in inflation and population growth, council spending per person has fallen 30 per cent in real terms since 2010. The housing budget has seen a cut of 48 per cent and the planning budget 55 per cent (Hambleton 2017). Overall, local government cuts have affected cities in the north of England more severely than those in the south.

Third, poor coordination and a lack of coherence has characterised urban policy in the UK. Urban policy under successive governments has suffered a lack of horizontal and vertical coordination across departments of central and local government (Atkinson 2003; Johnstone and Whitehead 2004). Many local initiatives have been largely isolated from mainstream government pro- 
grammes and services. Government has pursued separate short-term initiatives rather than taking a longer-term perspective driven by changes in mainstream services, with greater local coordination (Atkinson 2003). Fragmented and piecemeal projects and small resources have resulted in marginal achievements in many cases and policy has not been coordinated or strategic (Shaw and Robinson 1998).

Fourth, implementing one-dimensional urban policies has constrained the effectiveness of many national level approaches. The urban problem is multi-dimensional, but policy responses have often been too cautious and narrow. Policies have focused on a property-based approach (Turok 1992), or limited social programmes (Atkinson and Moon 1994), or business development (Parkinson 1989), or community regeneration (Taylor 2003; 2007). Successful urban regeneration requires the connection to be made between each of these physical, economic and social dimensions in combination.

Fifth, dealing with neighbourhoods as units isolated from their wider urban context has been a problem. There has been insufficient understanding of the function played by an area in the wider housing and employment markets, and of the relationship of neighbourhoods with surrounding areas. Artificial and arbitrary boundaries have been drawn around areas designated for neighbourhood regeneration, and issues of displacement, gentrification and leakage have been overlooked. It has also been argued that the explicit targeting of deprived areas has increased problems related to stigma and poor place image (Hastings and Dean 2003).

Sixth, there has been a consistent failure in realising community potential within regeneration schemes across the world. However, since the late 1990s in particular, communities have been placed at the heart of regeneration (Atkinson 2003; Taylor 2007). This reflects a communitarian view and a belief in self-help and social capital (Putnam 1993; 2000; Taylor 2003; 2007). This can be seen as a romantic notion considering the tensions and conflicts within communities; the tendency for burn-out or fatigue in these communities because of the demands of successive initiatives; and the challenges that face such communities (Atkinson 2003). Empowering and involving communities remains a major challenge within urban policy despite the lexicon surrounding this during the period of the Coalition and subsequent Conservative governments (CLG 2011).

Seventh, austerity politics and the abolition of a distinct urban policy in the UK has affected the delivery of traditional regeneration objectives (Crowley et al. 2012; O'Brien and Matthews 2016), although these have both been seemingly reversed by the Conservative government elected in December 2019. Throughout this period, there has been an absence of an urban policy as understood and implemented by UK national governments since 1968. Area-based social regeneration schemes were abolished and there was a shift to economic 
growth and productivity policies as a replacement, which were not necessarily targeted at those most deprived places left behind (Beatty and Fothergill 2013; 2016). This period of austerity was most strongly associated with the Coalition government under David Cameron and George Osborne, which came to an end with the vote for Brexit in 2016. The following Theresa May and Boris Johnson governments have shifted away from this approach, and there are suggestions, if not any concrete polices as yet, of a renewed traditional national urban policy in the context of the aim to re-industrialise areas in the midlands and the north of England as part of an industrial strategy.

The UK election in December 2019, won by the Conservative Party, highlighted the importance of infrastructure and investment for addressing a decade of economic challenges and austerity politics - particularly in 'towns left behind' (Bolton et al. 2020). The election manifestos of the major parties for the 2019 General Election explicitly and implicitly articulated a range of issues related to urban regeneration, though the actual word 'regeneration' was mentioned only three times in the Conservative Party manifesto (Conservative Party 2019) and once in the Labour Party manifesto (Labour Party 2019). The winning Conservative manifesto devoted a whole chapter to the theme of 'we will unleash Britain's potential', which focused on reviving towns and cities in towns left behind, a new deal for towns rather than big cities, and investing in large-scale transport infrastructure to redistribute economic growth. A key part of the plan is to 'level up' the UK's cities and regions to connect them and rebalance the economy away from the south east. 'Levelling up' (Policy Connect 2020), productivity and growth, and public spending on infrastructure and town centres have subsequently been the focus of the 2020 Budget and associated policy initiatives. The Stronger Towns Fund is a key recent development in terms of national urban policy. Announced in 2019, this is a $£ 1.6$ billion fund which will build on City Deals, which were agreed in 28 of England's biggest conurbations in the 2010s. $£ 1$ billion of the new fund will be allocated using a needs-based formula, with the remaining $£ 600$ million being available through a competitive process. The focus is on a combination of productivity, income, skills, deprivation indices and the proportion of the population living in towns, rather than cities. This targets funding at the left behind places with economies performing less well compared to the average, whose residents are living on lower incomes, and where larger proportions of the population have low skill attainment. This and other policies arguably witness the meaningful return to attention to national urban regeneration policy in the UK for the first time since the late 2000 s, prior to the global economic crash and subsequent era of austerity.

The change in approach to policy has been demonstrated in the first few months of 2020, with the UK's leaving of the European Union on 31 January being made possible by a Conservative government with a significant 80 -seat 
majority. The recent emphasis has been on town centre regeneration, business rates reduction and a focus on the micro scale of small and medium towns rather than the macro issue of Brexit which dominated the previous two governments from 2015-2017 and 2017-2019. The focus of the debate following the General Election has been on domestic priorities such as public services, particularly in the traditionally Labour towns of the midlands and north which were won by the Conservatives as part of the demolition of the so-called 'red wall' - the exact towns that are seen as being left behind (Bolton et al. 2020). There has also been a continued focus on productivity gaps in the context of the industrial strategy (HM Government 2017; What Works Centre for Local Economic Growth 2018) and through the UK Shared Prosperity Fund as a driver of national urban policy. This was announced in 2017 by the UK government as a replacement for EU Structural Funds. During the 2019 election campaign, the Conservative Party reiterated this pledge and committed to, at a minimum, match the size of the structural funds in each nation to directly replace EU structural funding contributions to regional development (House of Commons Library 2020). In the period 2014-2020, the European Union allocated the UK $£ 10.6$ billion, with the majority being distributed to peripheral regions in Wales, Scotland, the North East and the South West; therefore there is little direct association between these funds and urban policy.

Despite these categories of national urban policy problems, it is important to acknowledge that urban regeneration policies since the end of the Second World War have attempted to solve some of the most deeply entrenched and 'wicked' social and economic issues facing Western European and North American countries. Therefore, it is perhaps not surprising if government policies are not always entirely successful. Shaw and Robinson (1998) argued that urban policy had been characterised by a form of 'policy amnesia' in that there had been a failure to learn from past experiences. Within this context, 'research is rapidly forgotten ensuring that wheels have to be re-invented and long-established truths have to be rediscovered' (Wilks-Heeg 1996, p. 1264), which remains valid going into the 2020s.

\section{CONCLUSION AND THE SITUATION IN THE EARLY 2020S}

Cities around the globe continue to witness dramatic and profound changes in the early twenty-first century. Urban regeneration policies and strategies have played a part in these transformations, and at the same time there is a necessary role for urban regeneration in response to processes of urban change. The main changes which continue to be experienced, principally in advanced Western economies, are a decline of jobs in manufacturing; a growth of jobs in services; a growth of centres of entertainment and tourism in city spaces; construction 
of flagship buildings; staging of signature events; creeping suburbanisation of retail, business and leisure; the emergence of new types of usually smaller households; a sharpening of racial and ethnic divides; and the emergence of a climate of vulnerability and fear. Urban regeneration initiatives driven by central government, and experiences and responses at the city level, are constantly evolving. These have emerged in the context of the key major themes of the transition from production to information and consumption, the local impacts of globalisation, exclusion and threats to social cohesion, increasing social and cultural diversity in cities, the transition to entrepreneurialism and new forms of city governance, the rise of postmodern urban landscapes, and the growing challenges of climate change and sustainable development.

National urban policy in advanced economies tends towards phases and cycles of initiatives. Early physical, built environment approaches in the 1940s and 1950s gave way to a focus on area-based social welfare initiatives in the late 1960s and 1970s. From the 1980s, the focus on the private sector and economic regeneration led to property-led regeneration and the philosophy of public-private partnerships. Subsequently, communities and local authorities have been afforded a greater say in urban regeneration, and sustainability has been an inextricably integrated concern. From the late 1990s until the late 2000s, urban regeneration sought to combine economic, social and environmental dimensions, although policies appeared to be constrained by the scale of urban problems, resources and timescales, and the complex nature of governance and funding regimes. A period of austerity and the disappearance of area-based urban policy initiatives characterised the whole decade of the 2010s with a focus on economic and business growth, and devolution of powers to institutions such as directly elected mayors, of which there are 15 city mayors and nine metropolitan city-region mayors.

Economic growth and localism objectives characterised the approaches to urban regeneration throughout the Coalition and Conservative governments through the 2010 s and into the 2020s. There was a move away from the area-based and neighbourhood renewal programmes characteristic of New Labour due to the natural end of programmes, government austerity measures and different philosophical approaches to urban and economic policy. Arguably there has been no explicit national urban policy in the UK throughout the 2010s, and the issue remains in a state of flux at the time of writing in early 2020 with the election of a new Conservative government under Prime Minister Boris Johnson in late 2019. Early indications suggest an increase in borrowing and spending on towns left behind, high street regeneration, and large-scale infrastructure investment particularly connecting the north to the south of England. Additionally, Bolton et al. (2020) suggest that the government create a community wealth fund to invest in the most left behind neighbourhoods in the country, the majority of which are located in 
the 'red wall' areas in the midlands and north. This would take the form of a new permanent endowment funded by dormant assets to secure long-term support in the most 'left behind' neighbourhoods. The Stronger Towns Fund is distributed to 'left behind' neighbourhoods in the towns already identified for support by the government by acknowledging existing 'pockets of deprivation and neighbourhoods' that have missed out. Bolton et al. (2020) argue that the government should allocate funding directly to residents of peripheral housing estates and other areas such as coastal towns to contribute to community economic development initiatives. Another recommendation is that a proportion of the UK Shared Prosperity Fund should be invested into 'left behind' neighbourhoods as identified by the Indices of Multiple Deprivation (MHCLG 2019). The establishment of a joint cross-government and civil society task force on 'left behind' neighbourhoods is a final recommendation for national urban policy (Bolton et al. 2020) to consider evidence about how the issues in 'left behind' neighbourhoods could be addressed through local public spending bodies working together to support community action.

Overall, this chapter has illustrated how national urban policy over a period of more than 70 years has focused on what are currently termed by the government 'places left behind'. National urban policy in the UK has evolved sequentially through periods of economic boom exemplified by entrepreneurialism in the 1980s and the urban renaissance during the 2000s, and into slump eras such as the 1970s and late 2000s/early 2010s and subsequent recovery, as was showing by the late 2010s. This chapter has outlined a historic and contemporary overview of national urban policy and critiqued national urban policy initiatives during the postwar period in the UK. An overall policy evaluation has been presented, and a focus on the past decade and current urban policy situation indicated the extent to which there has even been an urban policy during the 2010s, and the extent to which there are indications of a re-emergence of a national urban policy. Key current issues are dealing with places left behind in the shadow of Brexit and the loss of EU funds, and re-industrialisation in the north through a new tranche of urban policies. In early 2020, it may be suggested that urban regeneration as a national government policy field is back on the agenda with a reversal of the idea of 'post-urban policy'.

\section{REFERENCES}

Andrew, C. and Goldsmith, M. (1998), 'From local government to local governance and beyond', International Political Science Review, 19, 101-117.

Atkinson, R. (2003), 'Urban policy', in N. Ellison and C. Pierson (eds), Developments in British Social Policy 2, Basingstoke: Palgrave Macmillan, 160-176.

Atkinson, R. and Moon, G. (1994), Urban Policy in Britain: The City, the State and the Market, London: Macmillan. 
Audit Commission (1989), Urban Regeneration and Economic Development: The Local Government Dimension, London: HMSO.

Beatty, C. and Fothergill, S. (2013), Hitting the Poorest Places Hardest: The Local and Regional Impact of Welfare Reform, Sheffield: CRESR.

Beatty, C. and Fothergill, S. (2016), The Uneven Impact of Welfare Reform: The Financial Losses to Places and People, Sheffield: CRESR.

Begg, I. (1999), 'Cities and competitiveness', Urban Studies, 36, 795-809.

Bolton, M., Day, R. and Leach, M. (2020), 'England's overlooked neighbourhoods: defining, understanding and regenerating "left behind" communities', Journal of Urban Regeneration and Renewal, 13, 116-123.

Clarke, N. and Cochrane, A. (2013), 'Geographies and politics of localism: the localism of the United Kingdom's coalition government', Political Geography, 34, 10-23.

CLG (Communities and Local Government) (2008), Transforming Places; Changing Lives: A Framework for Regeneration, London: CLG.

CLG (Communities and Local Government) (2009), The Credit Crunch and Regeneration: Impact and Implications, London: CLG.

CLG (Communities and Local Government) (2011), Regeneration to Enable Growth: What Government Is Doing in Support of Community-Led Regeneration, London: CLG.

Colomb, C. (2007), 'Unpacking New Labour's "urban renaissance” agenda: towards a socially sustainable reurbanization of British cities?', Planning Practice and Research, 22, 1-24.

Conservative Party (2019), Get Brexit Done: Unleash Britain's Potential - The Conservative and Unionist Party Manifesto 2019, London: Conservative and Unionist Party.

Couch, C. (1990), Urban Renewal: Theory and Practice, Basingstoke: Macmillan.

Crowley, L., Balaram, B. and Lee, N. (2012), People or Place? Urban Policy in an Age of Austerity, London: Work Foundation.

Davoudi, S. and Healey, P. (1995), 'City challenge: sustainable process or temporary gesture?', Environment and Planning C: Government and Policy, 13, 79-95.

Dear, M.J. (1995), 'Prolegomena to a postmodern urbanism', in P. Healey, S. Cameron, S. Davoudi, S. Graham and A. Madanipour (eds), Managing Cities: The New Urban Context, Chichester: Wiley, 27-44.

Edwards, C. and Imrie, R. (2015), The Short Guide to Urban Policy, Bristol: Policy Press.

Forrest, R. and Kearns, A. (2001), 'Social cohesion, social capital and the neighbourhood', Urban Studies, 38, 2125-2144.

Gripaios, P. (2002), 'The failure of regeneration policy in Britain', Regional Studies, 36, 568-577.

Hall, S. (2015), 'The rise and fall of urban regeneration policy in England 1965 to 2015', in F. Weber and O. Kühne (eds), Fraktale Metropolen: Stadtentwicklung zwischen Devianz, Polarisierung und Hybridisierung, Wiesbaden: Springer, 313-330.

Hall, T. and Barrett, H. (2012), Urban Geography, London: Routledge, 4th edition.

Hall, T. and Barrett, H. (2018), Urban Geography, London: Routledge, 5th edition.

Hall, T. and Hubbard, P. (1996), 'The entrepreneurial city: new urban politics, new urban geographies?', Progress in Human Geography, 20, 153-174.

Hambleton, R. (2015), 'Place-based leadership: a new perspective on urban regeneration', Journal of Urban Regeneration and Renewal, 9, 10-24.

Hambleton, R. (2017), 'The super-centralisation of the English state - why we need to move beyond the devolution deception', Local Economy, 32, 3-13. 
Hambleton, R. (2019), 'The new civic leadership: place and the co-creation of public innovation', Public Money and Management, 39, 271-279.

Harvey, D. (1989), 'From managerialism to entrepreneurialism: the transformation in urban governance in late capitalism', Geografiska Annaler, 71B, 3-17.

Hastings, A., Bailey, N., Bramley, G. and Gannon, M. (2017), 'Austerity urbanism in England: the "regressive redistribution" of local government services and the impact on the poor and marginalised', Environment and Planning A, 46, 2007-2024.

Hastings, A., Bailey, N., Gannon, M., Besemer, K. and Bramley, G. (2015), 'Coping with the cuts? The management of the worst financial settlement in living memory', Local Government Studies, 41, 601-621.

Hastings, A. and Dean, J. (2003), 'Challenging images: tackling stigma through estate regeneration', Policy and Politics, 31, 171-184.

Herbert, D. (2000), 'Towns and cities', in V. Gardiner and H. Matthews (eds), The Changing Geography of the United Kingdom, London: Routledge, 3rd edition, 190-212.

HM Government (2017), Industrial Strategy: Building a Britain Fit for the Future, London: HM Government.

House of Commons Library (2020), 'The UK Shared Prosperity Fund', Briefing Paper Number 08527, London: House of Commons Library.

Imrie, R. and Thomas, H. (1993), 'The limits of property-led regeneration', Environment and Planning C: Government and Policy, 11, 87-102.

Imrie, R. and Thomas, H. (eds) (1999), British Urban Policy: An Evaluation of the Urban Development Corporations, London: Sage, 2nd edition.

Jacobs, B.D. (1992), Fractured Cities: Capitalism, Community and Empowerment in Britain and America, London: Routledge.

Johnstone, C. and Whitehead, M. (2004), 'Horizons and barriers in British urban policy', in C. Johnstone and M. Whitehead (eds), New Horizons in British Urban Policy: Perspectives on New Labour's Urban Renaissance, Aldershot: Ashgate, $3-21$.

Jones, C. (2006), 'Verdict on the British Enterprise Zone experiment', International Planning Studies, 11, 109-123.

Jones, P. and Evans, J. (2013), Urban Regeneration in the UK, London: Sage, 2nd edition.

Kearns, A. (2003), 'Social capital, regeneration and urban policy', in R. Imrie and M. Raco (eds), Urban Renaissance? New Labour, Community and Urban Policy, Bristol: Policy Press, 37-60.

Labour Party (2019), It's Time for Real Change: The Labour Party Manifesto 2019, London: Labour Party.

Larkin, K. and Wilcox, Z. (2011), What Would Maggie Do? Why the Government's Policy on Enterprise Zones Needs to be Radically Different to the Failed Policy of the 1980s, London: Centre for Cities.

Latham, P. (2017), Who Stole the Town Hall? The End of Local Government as We Know It, Bristol: Policy Press.

Lawless, P. (2010), 'Urban regeneration: is there a future?', People, Place and Policy Online, 4, 24-28.

Lawless, P. (2011), 'Understanding the scale and nature of outcome change in area-regeneration programmes: evidence from the New Deal for Communities programme in England', Environment and Planning C: Government and Policy, 29, $520-532$. 
Lawless, P. and Beatty, C. (2013), 'Exploring change in local regeneration areas: evidence from the New Deal for Communities Programme in England', Urban Studies, 50, 942-958.

Lawless, P., Overman, H.G. and Tyler, P. (2011), 'Strategies for underperforming places', SERC Policy Paper 6, London: SERC.

Leunig, T. and Swaffield, J. (2008), Cities Unlimited: Making Urban Regeneration Work, London: Policy Exchange.

Levitas, R. (2005), The Inclusive Society? Social Exclusion and New Labour, Basingstoke: Palgrave Macmillan, 2nd edition.

Lowndes, V. and Gardner, A. (2016), 'Local governance under the Conservatives: super-austerity, devolution and the "smarter state", Local Government Studies, 42, 357-375.

Lupton, R., Fenton, A. and Fitzgerald, A. (2013), Labour's Record on Neighbourhood Renewal in England: Policy, Spending and Outcomes 1997-2010, London: CASE.

Lupton, R. and Fitzgerald, A. (2015), The Coalition's Record on Area Regeneration and Neighbourhood Renewal 2010-2015, London: CASE.

Matthews, P. (2012), 'From area-based initiatives to strategic partnerships: have we lost the meaning of regeneration?', Environment and Planning C: Government and Policy, 30, 147-161.

MHCLG (Ministry of Housing, Communities and Local Government) (2019), The English Indices of Deprivation 2019 (IoD2019), London: MHCLG.

Oatley, N. (1995), 'Urban regeneration', Planning Practice and Research, 10, 261-269.

Oatley, N. (ed.) (1998), Cities, Economic Competition and Urban Policy, London: Paul Chapman.

O’Brien, D. and Matthews, P. (eds) (2016), After Urban Regeneration: Communities, Policy and Place, Bristol: Policy Press.

Parkinson, M. (1989), ‘The Thatcher government's urban policy, 1979-1989', Town Planning Review, 60, 421-440.

Pike, A., Coombes, M., O'Brien, P. and Tomaney, J. (2018), 'Austerity states, institutional dismantling and the governance of sub-national economic development: the demise of the regional development agencies in England', Territory, Politics, Governance, 6, 118-144.

Pinto, R. (1993), The Estate Action Initiative, London: Ashgate.

Policy Connect (2020), Level Up Industry: Strengthening Regional Manufacturing, London: Policy Connect.

Potter, J. and Moore, B. (2000), 'UK Enterprise Zones and the attraction of inward investment', Urban Studies, 37, 1279-1312.

Pugalis, L. and McGuinness, D. (2013), 'From a framework to a toolkit: urban regeneration in an age of austerity', Journal of Urban Regeneration and Renewal, 6, 339-353.

Putnam, R.D. (1993), Making Democracy Work: Civic Traditions in Modern Italy, Princeton, NJ: Princeton University Press.

Putnam, R.D. (2000), Bowling Alone: The Collapse and Revival of American Community, New York: Simon and Schuster.

Raco, M. (2007), Building Sustainable Communities: Spatial Development, Citizenship, and Labour Market Engineering in Post-War Britain, Bristol: Policy Press.

Rhodes, J., Tyler, P. and Brennan, A. (2005), 'Assessing the effect of area-based initiatives on local area outcomes: some thoughts based on the national evaluation of the Single Regeneration Budget in England', Urban Studies, 42, 1919-1946. 
Roberts, P. (2017), 'The evolution, definition and purpose of urban regeneration', in P. Roberts, H. Sykes and R. Granger (eds), Urban Regeneration, London: Sage, 2nd edition, 9-43.

Robson, B.T., Bradford, M.G., Deas, I., Hall, E., Harrison, E., Parkinson, M., Evans, R., Harding, A., Garside, P. and Robinson, F. (1994), Assessing the Impact of Urban Policy, London: HMSO.

Shaw, K. and Robinson, F. (1998), 'Learning from experience? Reflections on two decades of British urban policy', Town Planning Review, 69, 49-63.

Shaw, K. and Robinson, F. (2010), 'UK urban regeneration policies in the early twenty-first century: continuity or change?', Town Planning Review, 81, 123-149.

Short, J.R. and Kim, Y-H. (1999), Globalization and the City, Harlow: Longman.

Sissons, A. and Brown, C. (2011), Do Enterprise Zones Work? An Ideopolis Policy Paper, London: The Work Foundation.

Smith, I., Lepine, E. and Taylor, M. (eds) (2007), Disadvantaged by Where You Live? Neighbourhood Governance in Contemporary Urban Policy, Bristol: Policy Press.

Soja, E.W. (1995), 'Postmodern urbanization: the six restructurings of Los Angeles', in S. Watson and K. Gibson (eds), Postmodern Cities and Spaces, Oxford: Blackwell, $125-137$.

Stewart, M. (1987), 'Ten years of inner cities policy', Town Planning Review, 58, $129-145$.

Tallon, A. (2013), Urban Regeneration in the UK, London: Routledge, 2nd edition.

Taylor, M. (2003), Public Policy in the Community, Basingstoke: Palgrave.

Taylor, M. (2007), 'Community participation in the real world: opportunities and pitfalls in new governance spaces', Urban Studies, 44, 291-317.

Tiesdell, S. and Allmendinger, P. (2001), 'Neighbourhood regeneration and New Labour's third way', Environment and Planning C: Government and Policy, 19, 903-926.

Turok, I. (1992), 'Property-led urban regeneration: panacea or placebo?', Environment and Planning A, 24, 361-379.

What Works Centre for Local Economic Growth (2018), Developing Effective Local Industrial Strategies, London: What Works Centre for Local Economic Growth.

Wilks-Heeg, S. (1996), 'Urban experiments limited revisited: urban policy comes full circle?', Urban Studies, 33, 1263-1279. 